Péter HEINDL

DOI: 10.15170/DIKE.2020.04.02.04

Legal Aid Service

Számá Dă Noj Association

\title{
Were there any Racial Legislations against the Roma during the Horthy Era?
}

Hungarian historians still question the fact that in the Hortby era there were racially discriminative legislations in force regarding all Roma. However, by analyzing contemporary legislation, it can be proven that in the period between the two world wars the Roma people suffered severe institutional discrimination in Hungary. The present study aims to buttress up this argument. The discrimination was based on a military emergency decree issued in the middle of the First World War. This decree was not repealed after the war, but the situation of the Roma was instead aggravated by the new decrees built on it. These decrees have been impacting the Roma even to this day, as they have been obstacles to social integration for many decades. The author of this paper and his colleagues intend to publish a collection of the approximately fifty decrees of the era they have collected that contained legislations aimed at the Roma in the near future.

Keywords: the Horthy era, decree legislation, military emergency decrees, discrimination, wandering-Gypsies, settled Gypsies, anti-Roma prejudices, legal constraints of Roma integration

\section{A contentious issue}

I have recently read a study by Lásそló Karsai and another by Attila Landauer in a volume, titled 'The Roma Holocaust in Eastern Europe I." published last year. From these studies as well as from two other studies published in the volume, I believe even an already informed reader could gain a new array of information about the fate of the Roma during World War II.

However, a serious and debatable statement caught my eye in both Karsai's and Landauer's writing. In one of his sentences Karsai mentions that he thinks that during the Horthy era, There was no developed state Gypsy politics, the authorities did not deal with the Gypsies, or if yes, then just with the wandering-gypsies.' Landauer also writes about this issue in more detail analyzing and, in some measure quoting the era's 'basic decree concerning the wandering-Gypsies', the number 15.000/1916. Interior Ministerial decree on wandering (tent-living) Gypsies, as well as three other decrees $^{3}$ that were either given by the Interior Minister as an interpretation of the 'basic decree' or

\footnotetext{
${ }^{1}$ KARSAI, From the Roma Holocaust to the Porajmos, in the light of the latest specialist literature; LANDAUER, The Holocaust of the Hungarian Roma - facts and new data.

2 KARSAI, From the Roma Holocaust to the Porajmos, in the light of the latest specialist literature 54.

${ }^{3}$ Mezey - Pomogy - TAuber, A magyarországi cigánykérdés dokumentumokban 1422-1985 [The Hungarian Gypsy question in documents 1422-1985]. All the decrees mentioned in this paper I quoted from this collections of documents.
} 
as an addition to it. These are special legal acts: they were issued under the exclusive jurisdiction during the war governments. However, contrary to the intentions of their issuers and the law that had allowed them to be created, the governments of the Horthy era maintained and applied these decrees even after World War II. Nay, they implemented additional decrees to their enforcement and supplementation.

According to Landaner's opinion, certain contemporary authors incorrectly, '...indicate that the legislations referring to the wandering Gypsies applied to the entire domestic Gypsy population'. I, however, think that it is Landauer who, in this case, fundamentally misunderstood something. So what is it about?

\section{How can the legal discrimination of the Roma people in general be proven?}

The decree $15.000 / 1916 .{ }^{5}$ in its introductory part and section 1, immediately distinguishes two well-defined legal entities. The first subsection of section 1 sets out the basic purpose of the decree, stating: 'Gypsies are probibited from the accustomed wandering'. How does it intend to achieve its goal for the Roma as a whole? On the one hand, by designating in the second subsection of section 1 a legal entity, the 'wandering-Gypsy', and then immediately defining what type of person shall be understood as such: 'The person who is incapable of confirming a proper place of residence shall be regarded as a wandering-Gypsy'. Here still remains a category to be defined, namely the concept of "proper place of residence'. The definition is included in the introductory part of the decree when it mentions to whom the provisions of the decree do NOT apply. To put it literally: 'However these provisions do not apply to the settled Gypsy, i.e. to those who have a proper place of residence and who are therefore known to the local authorities'. Thus, we can speak of a proper place of residence if a Roma person 'settled down'. The 'settlement' shall be proved apart from the actual place of residence by the fact that this person is 'known to the local authorities.' The 'wandering-Gypsy' as a legal entity, therefore, is defined relatively precisely in the decree, and it also states that the provisions of this legislation shall only apply to this legal entity. There is, however, one exception, a single provision, which in turn does not apply to that person, but to the 'settled Gypsies', viz. every other Roma apart from the 'wandering-Gypsies', meaning the vast majority of the ethnic group. ${ }^{6}$ The third subsection of section 1 is where this provision is contained: 'If the Gypsy proves that they have a proper place of residence, but they are in a different place, and them being there is not sufficiently justified, the police have to order them to their proper place of residence, or have to have them escorted there by force'. This provision is supposed to serve the basic goal of the decree, which is to 'prohibit Gypsies from their accustomed wandering', namely concerning all the Roma, who are not the part of the main target group of the decree, the legal entities categorized as 'nomad-Gypsies'.

For the police-gendarmerie representatives of the law, most of whom obviously do not have a legal degree, the number 151.041/1917. Interior Ministerial circulars decree on how to

\footnotetext{
${ }^{4}$ LANDAUER, The Holocaust of the Hungarian Roma - facts and new data 121, footnote 134.

${ }^{5}$ MeZey - Pomogy - TAuber, A magyarországi cigánykérdés dokumentumokban 1422-1985 [The Hungarian Gypsy question in documents 1422-1985] 183-191.

${ }^{6}$ It should be noted here that almost $89 \%$ of the Roma in Hungary were already classified as 'permanently settled' according the first comprehensive 'Gypsy-census' of 1893. Outside of this group the census put sligthly more than $3 \%$ of them to be the 'nomad-Gypsy', and close to $7.5 \%$ of them to be 'staying at one place for a longer period of time' cathegory. See POMOGYI, Cigánykérdés és cigányügyi igazgatás a polgári Magyarországon [Gypsy issue and administration in the civil Hungary] 7.
} 
proceed with the registered gypsies, ${ }^{7}$ served as an explanation, which even emphasizes the difference between the two legal entities, justified by the fact that certain police authorities have had been misinterpreted the basic legal act. In the second paragraph of the first Chapter of this circular the legislator firstly reiterates with regards to the 15.000/1916. basic decree that the decree cited above is therefore limited to the wandering-Gypsies and for that, it states in the second subsection of section 1 that from the perspective of this decree only those shall be and can be considered wandering-Gypsies, who are unable to confirm a proper place of residence.' Immediately in the following subsection, the text of the circular specifies the only exception where the basic decree does not contain a provision for the 'wandering-Gypsies': If a Gypsy proves a proper place of residence, but stays in another and it is not properly justified, the police shall order or forcibly escort the Gypsy to it'. From the text it may also become clear even for the laymen that the number 15.000/1916. basic decree does not use the category 'wandering-Gypsy' in the second subsection of section 1, then in the third subsection the term 'Gypsy' because of a 'terminological inaccuracy', but because it defines two different legal entities and because these two legal entities are subjects to different provisions. (Provisions regarding the wandering-Gypsies, who are still 'wandering' to the authorities, their escort to their designated place of residence, their registration, etc. are otherwise laid down in section 2 and the following sections of the basic decree. The rules about the already registered Roma, who repeatedly 'wander' away from their designated place of residence are contained in section 13.)

Now let us examine in substance that in legal terms what was meant by the restriction which applied to all Roma outside of the even more strictly restricted "wandering-Gypsies" from 1916 onwards for a long period of time!

The restriction meant that the members of the police had the discretionary (i.e. based on free judgment) right to decide whether the stay of any Roma, who was in a different place than their proper place of residence 'sufficiently justified' or not. If they found that the stay was not sufficiently justified, the legal entity was brought to the authorities (according to the recollections preserved: more than once beaten up) and then ordered that person to their place of residence or forcibly escorted them there.

\section{The 'overfulfilment' of decrees in law enforcement}

Official documents found in the archives and audio recordings of recollections also confirm that the decree was consecutively overfulfilled by the anointed guardians of the law.

In more than one case, if the person involved in the decree moved to another village to start a family or cohabitation, the gendarmeries still insisted on them moving back to their old place of residence. It also happened, that when someone was reluctant to move back, their hovel was set on fire. ${ }^{8}$

Then, for example, a gendarmerie report states that to supervise the 1916 decree of the Ministry of Internal Affairs, on one of the infamous 'Gypsy-raids' that were introduced in 1928, a young Roma lady was detained for being in another village, less than a kilometer away from her

\footnotetext{
7 Mezey - Pomogy - TAuber, A magyarországi cigánykérdés dokumentumokban 1422-1985 [The Hungarian Gypsy question in documents 1422-1985]. 194-199.

${ }^{8}$ HAVAS, A baranyai megyei teknóvájó cigányok [The tub cutter Gypsies of Baranya] 78.
} 
place of residence, the Roma segregation of Kisbicsérd, at the time of the raid and the authorities deemed this to be 'unauthorized wandering?'

Moreover, we can find an example for when considering the restriction of the movement of the Roma in-between settlements the local village leadership decided that the Roma of the segregation could not even enter their village without a permit. And when the 60 years old 'Gypsy-judge' (the voivode) entrusted by the authorities to lead the segregation nevertheless went to the town hall to complain about it and resisted the town crier when he forcibly made him return to the segregation in the open street, it was not the town crier, but the elderly Gypsy judge, who was the sentenced by the court to be removed from his post and eight months of imprisonment for enforceable violence and light bodily harm against the official personnel. ${ }^{10}$

(This story has a tragic ending. Years later, the village of the former Gypsy judge became one of the Transdanubian municipalities from which not only the inhabitants of the Jewish community but after their deportation. the Roma were deported as well. In the fall of 1944, the then 69-year-old István Kolompár Senior, who had previously served his eight-month prison sentence up until the last day, was taken to the Csillag Fortress by force to Komárom with the other Roma inhabitants of Kisbicsérd and Nagybicsérd. Although, from there those who were deemed to be unable to work and survived the inhumane conditions of the camp set up in the fortress were released to go home later, the German soldiers who conducted the selection in Komárom, declared Kolompár, despite his old age, as well as other elderly Roma people and others, who have just turned thirteen 'able to work' and deported to Germany. The elderly man could not survive the hell of the Nazi concentration camps. His name was marked as 'Ung-Zig', meaning 'Hungarian Gypsy', on the surviving compound list of the Dachau concentration camp. ${ }^{11}$ In Bicsérd, there is a memorial for World War I and World War II. There is a stone plaque on it with names of the victims (or at least some of them) of the Shoah and the Porajmos from the village as well as the fallen soldiers of Bicsérd. The name István Kolompár Senior is amongst the names under the sign: 'Victims of World War II.')

At that time and for a very long time after, the vast majority of the Roma - with the exception of the narrow circle of the 'genteel' musician Gypsies and a few more well-off 'Gypsy descendent' people - lived in the Roma segregations under miserable conditions. Those, who belonged to the vast majority had every chance to become the subject of police proceedings based on the number 15.000/1916 Interior Ministerial decree leaving their place of residence even with the intention of seeking employment. If they dared to leave their home at all. After all, they were the ones who were subject to the prejudices of the majority of the society ('they will surely steal, break in and beg!'). These prejudices have obviously defined (as they often still do)

\footnotetext{
${ }^{9}$ MNL BML [National Archives of Hungary, Baranya County Archives] Report Number 112/1943 of 1943, the 27th of May, to the Supreme Chief Magistrate Of Szentlörinc Concerning the Gypsy-Raid by the Gendarmerie of Szabadszentkirály. The document that can be found in the retention of documents concerning the Administrative Institution of the Supreme Chief Magistrate. It is quoted by Péter Bernáth in his Roma Collection compiled for the Museum of Ethnography's catalog of documents. (The catalog of documents was made available to me by Péter Szuhay, ethnographer, whom I hereby would thank for it.)

10 MNL BML [National Archives of Hungary, Baranya County Archives] The complete file of the number B. II. 2564/1937 criminal case can be found among the files of the Royal Court of Pécs.

11 The list of those from Dachau and four other concentration camps whom were marked as 'Ung-Zig' [Hungarian Gypsies] was published by János Bársony. See BÁRSONY - DARÓCZY, Kali trash - fekete félelem, Pharrajimos szétvágatás, Samudaripen - legyilkolás [Kali trash - black fear, Pharrajimos - cutting apart, Samudaripen - murder] $227-277$.
} 
the thinking of the police forces as well. But what is crucial from a legal perspective: the discretionary powers granted to the authorities in the decree applied only to the Roma, namely all the Roma, meaning a group of people defined on a 'racial basis' (according to the contemporary language)!

It appears that when formulating the rules about the legal entities, the 'Gypsy-raid circular decree' of 1928, officially known number 257.000/1928. Interior Ministerial decree on the more effective regulation and collection of new data of the wandering Gypsies ${ }^{12}$, also followed the terminology of the basic decree of 1916. Some provisions of the raid-decree were not only applied to the 'wandering-Gypsies' or gypsies in general, but others as well. This is clearly already indicated in the goal-setting of the first sentence of the circular when it states, that the prevention of the "wandering" and the dealings of the "wandering Gypsy" and other similar entities falling under the same evaluation, that endanger the public order, the public safety and the public health, and in relation with these the radical solution of the Gypsy-issue is a non-dilatory task of the state'. Here, the term 'wandering Gypsy' refers to the Roma who are wandering. It does not refer to the term defined in the decree of 1916, 'wandering-Gypsy', which is written in one word in Hungarian, and written hyphenated in this English translation. In regard the latter the fifth point of the circular specifically emphasizes that 'concerning the wandering-Gypsies brought to the police authorities the number 15.000/1916. Interior Ministerial decree should otherwise be applied in light of the changed circumstances'.

The fourth point of the circular of 1928 treats the Roma brought to the authorities and other persons in the same manner, when it provides that amongst them 'those, who are either suspected of punishable criminal offense covered in the Act XXI of 1913 or other acts shall be brought to the court of competent jurisdiction.' This particular act the Act XXI of 1913. deals with 'perilous shirkers'. According to this, 'those able-bodied individuals dependent on having a wage, who wander to avoid work or otherwise pursues a work-avoiding lifestyle' are punishable for the trespass of being a perilous shirker. So, for someone to be punishable, it is not enough to wander, but it has to be done with the purpose of avoidance of work. In this case, the 'wandering' is only punishable, if the person in question is an individual dependent on having a wage, meaning that they have no assets or any legitimate income acquired by the means of work by which they are able to support themselves and they, for example, do not have any family member who would take care of them. This provision applies to everyone, whether the individual is a Roma or another person.

There is however also one provision of the 'Gypsy-raid circular' of 1928 that applies to only the 'wandering gypsies' and not to 'other elements subject to similar treatment.' According to the second point of the circular: 'the wandering gypsies, who wander to avoid work or do so in the name of work or seeking employment shall be intercepted and brought to the nearest police station with armed escort by the public security bodies.' This provision is fully in line with the third paragraph of the 'basic decree' of 1916. In essence, what it adds to it is that if a Roma person wanders' (whatever this term is supposed to mean) then them being stopped and being brought to the authorities with armed escort is mandatory. With this, the 1928 raid-decree has now also made it clear that that in regard to a 'wandering' Roma person the police authorities cannot even consider that them staying out of their proper place of residence for work or seeking employment might be a sufficient justification. In contrast, if a Roma person was 'simply' not on their proper place of residence,

12 Mezey - Pomogyi - TAuber, A magyarországi cigánykérdés dokumentumokban 1422-1985 [The Hungarian Gypsy question in documents 1422-1985]. 200-201. 
the police was still free to decide whether their stay was sufficiently justified by the 'basic-decree' of 1916, as the 'Gypsy-raid circular' of 1928 did not repeal the number 15.000/1916. Interior Ministerial decree concerning the Roma who had a proper place of residence but who were not staying there at that moment.

Certainly, in Hungary the number 15.000/1916. Interior Ministerial decree has become the first of the series of 'racially-based' central provisions of the 20th century, even coming a few years before the 'numerus clausus' law (Act XXV of 1920), institutionally restricting the further education of the Jewish youth.

Attila Landauer draws a rather misleading conclusion in his above-mentioned study when he states that 'there were no regulations in Hungary before the World War II that were valid for every Gypsy person on racial basis. ${ }^{13}$ Although the decree of 1916 did not contain the same provisions for all the Roma, it did discriminate against all the Roma, undeniably on racial grounds.

The discriminatory nature of the decree and the subsequent decrees that were later based on it raises many questions to be answered. Among other things an important question is how these decrees can be compared to the discriminatory legal acts against Jewish people. It is also important to clarify the role of these decrees in the process that has led to thousands of Hungarian Roma people to eventually fall victim to the genocidal politics of the Nazis and their domestic allies. These are unavoidable questions. I, however, at this moment would like to draw the attention to another impact of the discriminatory legislations and its effect on the generation of Roma people at that time and later on.

In his sentence quoted in the beginning of my paper, Karsai states, that at the beginning of the era, 'there were no developed state Gypsy politics...' It was certainly not developed indeed, but a state policy affecting the fate of the Roma in Hungary in a peculiar way has still existed in the period between the two World Wars. By keeping the number 15.000/1916. Interior Ministerial decree in effect after the World War I and by the new decrees that were built on it, the state sought to ensure that the presence of the Roma coming from other settlements shall not disturb the non-negligible part of the local non-Roma majority, that had already considered the problem to be mainly 'racial in nature'.

Thus, the governments appointed by Horthy continued to grant the local police the right to restrict the movement of the Roma. By granting this right the officials were in fact granted the authority for that if according to their subjective perceptions the presence of the Roma 'wandering away' from home was endangering the peace of the majority they had the right to 'preventively' turn those, with an aim to escape the hopelessness of the world of hovels, back home, restricting their freedom of movement to the administrative boundaries of the village to which the Roma settlement belonged to.

The state, by this simple arrangement with the purpose of 'racial defense', has, for decades, 'put aside' a serious societal problem, that actually only became even more serious for "being put aside." Extensive, central measures to be taken with the intention of significantly improving the situation of the Roma living in poverty in the segregations were yet to be awaited for a long-long time.

\footnotetext{
13 LANDAUER, The Holocaust of the Hungarian Roma - facts and new data 153.
} 


\section{A collection of sources for further research}

Together with the decrees discussed above, there were about fifty decrees in effect during peacetime between the two world wars, which contained provisions specifically concerning the Roma.

These regulations did not only restrict the freedom of movement of the Roma, but also restricted their right to work and to trade as well as their property rights. Several decrees have required special epidemiological requirements to be applied to the Roma. Under the pretext of fighting epidemics the Roma had to be humiliated in their human dignity. Other regulations required the authorities to subject the Roma to more intensified public security checks than other citizens.

These decrees have now been collected with the collaboration of some of the employees (primarily Brigitta Bogdán and Gabriella Dezsố) of the Gandhi High School and its parent institution, a non-profit company, and with the help of Eszter Cs. Herger, Professor of the Department of Legal History at the University of Pécs Faculty of Law. We hope to be able to publish this collection of legislation soon.

\section{Bibliography and sources}

BÁRSONY János - DARÓCZI Ágnes: Kali trash - fekete félelem, Pharrajimos - szétvágatás, Samudaripen - legyilkolás. A romák sorsa a Holocaust idején Magyarországon II. [Kali trash - black fear, Pharrajimos - cutting apart, Samudaripen - murder. Fate of Roma in Hungary during the Holocaust II]. Budapest 2015

HAVAS Gábor: A baranyai megyei teknővájó cigányok [The tub cutter Gypsies of Baranya] In: ANDOR Mihály (ed.): Cigányvizsgálatok [Gypsy inspections]. Budapest 1982

KARSAI László: From the Roma Holocaust to the Porajmos, in the light of the latest specialist literature. In: LANDAUER Attila (ed.): The Roma Holocaust in Eastern Europe I. Hungary and Romania - A roma holokauszt Kelet-Európában I. Magyarország és Románia. Budapest 2019

LANDAUER Attila: The Holocaust of the Hungarian Roma - facts and new data (in English and in Hungarian) In: LANDAUER Attila (ed.): The Roma Holocaust in Eastern Europe I. Hungary and Romania - A roma holokauszt Kelet-Európában I. Magyarország és Románia. Budapest 2019

MeZEy Barna - POMOGYI László - TAUBER István: A magyarországi cigánykérdés dokumentumokban 1422-1985 [The Hungarian Gypsy question in documents 1422-1985]. Budapest 1986

POMOGYI László: Cigánykérdés és cigányügyi igazgatás a polgári Magyarországon [Gypsy issue and administration in the civil Hungary]. Budapest 1995 